\title{
Currency Networks, Bilateral Exchange Rate Volatility and the Role of the US Dollar
}

\author{
Michael Bleaney and Mo Tian \\ School of Economics, University of Nottingham
}

\begin{abstract}
We investigate monthly bilateral exchange rate volatility for a large sample of currency pairs over the period 1999-2006. Pegs (particularly to the US dollar) and managed floats tend to have lower volatility than independent floats. A deeper investigation shows that the peg effect operates almost entirely through currency networks (i.e. where two currencies are pegged to the same anchor currency), and the lower volatility of US dollar pegs reflects the size of the US dollar network. Managed floats show clear evidence of tracking the US dollar, further increasing the effective size of the US dollar network. Inflation undermines the currency-stabilizing effect of peg networks. Currencies in smaller peg networks have higher unweighted but not trade-weighted exchange rate volatility, which is consistent with anchors being chosen to minimize trade-weighted volatility. The size of the effective US dollar network revealed here is a plausible explanation of the rarity of basket pegs. Volatility also reflects a range of structural factors such as country size, level of development, population density, inflation differentials and business cycle asymmetry.
\end{abstract}

JEL No.: F3

Keywords: exchange rate volatility; currency peg; inflation.

Authors' contact information:

Professor M F Bleaney, School of Economics, University of Nottingham, University Park, Nottingham, NG7 2RD, U.K. E-mail: Michael.bleaney@nottingham.ac.uk; tel. +44 115951 5464; Fax +44 115951 4159 


\section{Introduction}

In theoretical models, an exchange rate peg generally has two effects: it removes monetary independence, so that the domestic price level is determined by the foreign price level; and it also reduces exchange rate uncertainty and flexibility, including the capacity to respond to shocks. There has been extensive empirical research on both of these issues (e.g. Bleaney and Francisco, 2005, and Ghosh et al., 2002, for inflation; and Broda, 2004, and Edwards and Levy-Yeyati, 2005, for terms-of-trade shocks).

This paper focuses on the relationship between the exchange rate regime and exchange rate volatility, where "regime" is meant here in the broad sense of what anchor currency to choose for a peg (or to track in a managed float) as well as the degree of flexibility. The contribution of the paper is that these issues have not previously been the subject of detailed study. The paper addresses such questions as:

(a) Are currency networks (currencies pegged to the same anchor) characterized by low internal bilateral exchange rate volatility, so that the effectiveness of a peg depends very much on the anchor chosen, as one would naturally expect?

(b) Are currency network effects, if any, sensitive to certain conditions, such as the inflation rates of the countries concerned? In other words, does monetary instability undermine the benefits of pegging?

(c) Can we obtain any insight into the typical behaviour of managed floats, about which little is known? Is there any evidence that they are quasi-pegs, and in particular quasi-pegs to the US dollar?

Previous research has established that pegging reduces exchange rate volatility, without yielding much insight into the questions above. Flood and Rose (1995) show 
that real exchange rate volatility amongst the major currencies has been much greater in the post-1973 era of floating rates than under the Bretton Woods system, even though general macroeconomic volatility has not increased. Klein and Shambaugh (2008) demonstrate that since 1973 pegs have had significantly lower bilateral volatility against the anchor currency, and also lower multilateral volatility, than nonpegs, although there is a strong element of tautology in this result, since they classify the regime as a non-peg whenever the exchange rate moves outside a $+/-2 \%$ band during the year (unlike the IMF classification system, which allows pegs to be devalued). Bleaney and Francisco (2010) find that countries classified by the IMF as independent floats have significantly higher real effective exchange rate volatility than all other regimes, including managed floats, after controlling for other factors. Meissner and Oomes (2009) investigate the determinants of anchor currency choice, and their results broadly support the interpretation that anchor currencies are chosen to minimize the transaction costs associated with exchange rate volatility.

Other research has focused on the fact that some currency pairs are much more volatile than others, whatever the exchange rate regime. Bayoumi and Eichengreen (1998) show that optimum currency area (OCA) theory helps to explain bilateral exchange rate volatility amongst 21 industrial countries. Devereux and Lane (2003) use a much larger sample of countries and suggest that, after controlling for OCA factors, volatility is lower in countries with more external debt. Bravo-Ortega and di Giovanni (2005) find that country pairs which are more similar in the geographical origins of their imports have lower bilateral real exchange rate volatility, which they attribute to symmetry in the transmission of external shocks. None of these studies of 
bilateral exchange rate volatility seriously examine exchange rate regime effects. ${ }^{1}$ A further strand of research has concentrated on the negative relationship between trade openness and real effective exchange rate volatility (Bleaney, 2008; Bravo-Ortega and di Giovanni, 2006; Hau, 2002).

For many purposes we are most interested in effective exchange rates (nominal or real), but these are aggregations of bilateral rates, and the weights differ across countries. Specifically, a given bilateral rate tends to have more weight in the effective exchange rate of the smaller country. Consequently, it is unclear what proportion of the cross-country variation in effective exchange rate volatilities derives from the underlying bilateral volatilities rather than from weighting differences. The aggregation loses a lot of information. In this paper, like Bayoumi and Eichengreen (1998) and Devereux and Lane (2003), we avoid this problem by investigating all possible pairs of bilateral volatilities, on the principle that, although the exchange rate between currencies $\mathrm{A}$ and $\mathrm{B}$ can be directly calculated from their rate against $\mathrm{C}$, this is not true of volatilities, because the covariance term represents a degree of freedom. What is new in our study is a comprehensive analysis of regime effects, as well of structural and macroeconomic factors.

The paper is structured as follows. The empirical model is described in Section Two, and results are presented in Section Three. Section Four concludes.

\footnotetext{
${ }^{1}$ Bravo-Ortega and di Giovanni (2005) include exchange rate regime effects in some regressions as a robustness test, and find them significant, but they do not examine them in any detail.
} 


\section{The Model}

Several previous papers contain theoretical models that illustrate how exchange rate volatility can arise from price stickiness (e.g. Hau, 2002) or local technological shocks (Bravo-Ortega and di Giovanni, 2005). The theoretical models in this literature tend to be described as "illustrative" 2 and do not provide precise guidance to the structure of empirical models, which follow the prototype of Bayoumi and Eichengreen (1998) fairly closely, focusing on the implications of OCA theory. Rather than present a detailed theoretical model here, we give references to support the inclusion of the variables chosen in the empirical specification. As in previous studies, our model assumes that the bilateral volatility of any pair of countries is a function of structural factors closely informed by OCA theory. We add to this a detailed analysis of currency regime effects. We estimate the following crosssectional regression across all country pairs:

$$
V L T_{i j}=\alpha+\underline{\beta} \cdot \underline{\operatorname{CONTROLS}}_{i j}+\underline{\gamma} \cdot \underline{\operatorname{REGIME}} \underline{\mathrm{Ej}}_{i j}+\varepsilon_{i j}
$$

where $V L T_{i j}$ represents a measure of the bilateral volatility of currencies $i$ and $j$; $\underline{C O N T R O L S}_{i j}$ is a vector of control variables; $\underline{\operatorname{REGIME}}_{i j}$ is a vector of dummy variables for the exchange rate regime; $\varepsilon_{i j}$ is a random error term; and $\alpha, \underline{\beta}$ and $\underline{\gamma}$ are parameters to be estimated. In detail the variables are as follows.

\footnotetext{
${ }^{2}$ This actual word is frequently used (e.g. Bravo-Ortega and di Giovanni, 2005, 2006; Devereux and Lane, 2003).
} 


\section{Volatility}

The volatility of the bilateral exchange rate between countries $i$ and $j\left(Z_{i j}\right)$ is calculated as the standard deviation of changes in the logarithm of the end-of-month rate recorded in the IMF International Financial Statistics database over the period from January 1999 to December $2006:^{3}$

$$
V L T_{i j}=\operatorname{STDEV}\left(d \ln Z_{i j}\right)
$$

\section{Control variables}

We use a number of control variables that capture non-regime influences on bilateral exchange rate volatility. Except where indicated, data are from the World Bank's World Development Indicators database. Full details of data sources are given in the Appendix

1) Land area per capita is defined as the logarithm of the ratio of land area to population, averaged over the pair of economies $i$ and $j$. Where economies are less densely populated, they are more likely to specialize in primary products and are therefore more exposed to terms-of-trade shocks (Cashin et al., 2004).

2) Trade is the logarithm of one plus the ratio of bilateral trade between $i$ and $j$ to GDP, averaged over the pair of economies $i$ and $j$. Various theoretical and empirical studies have indicated that it is correlated with exchange rate volatility (Bergin et al., 2006; Bravo-Ortega and di Giovanni, 2005; Choudhri and Khan, 2005; Hau, 2002).

\footnotetext{
${ }^{3}$ The start date coincides with the formation of the euro.
} 
3) Cycle asymmetry is the standard deviation of the difference between the logarithmic annual GDP growth rates of countries $i$ and $j$ over the period 1995-2005. This is a measure of asymmetric shocks which is found to be positively correlated with volatility by Devereux and Lane (2003), as is predicted by optimum currency area theory.

4) Economic size is the logarithm of GDP in 2000, averaged over the pair of economies $i$ and $j$. Larger economies tend to have greater exchange rate volatility because there are more opportunities for internal trade (Devereux and Lane, 2003).

5) Inflation is clearly likely to be associated with greater exchange rate volatility, because of its effect on equilibrium nominal exchange rates. Even if countries $i$ and $j$ have similar inflation rates, because higher inflation rates are more unstable, more exchange rate instability is to be expected in this case. For this reason we include both the inflation average of the two countries $i$ and $j$ and the absolute value of the inflation differential between them. Nevertheless inflation has been neglected in previous empirical studies of bilateral volatility, although it has been shown to be a significant determinant of real effective exchange rate volatility (Bleaney and Francisco, 2010). Inflation for each country is the annual average percentage increase in the consumer price index over the years 1999-2006. We did not find external debt and other financial variables, as used by Devereux and Lane (2003), to be significant, and they are omitted.

6) GDP per capita (in logarithms) is a standard control variable to capture the effect of different productivity levels; its sign may be positive or negative. We also include dummy variables for the case where either or one of the two 
countries is an industrial economy, according to the IMF definition. These variables are included in order to reduce possible omitted variables bias in the regressions.

\section{Regime dummies}

We use two alternative systems for classifying exchange rate regimes. One is the IMF's official de facto classification system that has been in force since 1999. Apart from currency unions, this identifies seven different regimes at the end of each quarter: independent floats (in which the exchange rate "is market-determined", with intervention aimed only "at moderating the rate of change or the degree of fluctuation, rather than establishing a level"); managed floats (no specified exchange rate path or target, but with more intervention than would meet the criteria for an independent float); and five types of peg or band. A peg allows a fluctuation of $\pm 1 \%$ vis-à-vis the anchor currency or currency basket, whereas a band permits wider fluctuations. In crawling pegs or bands, the central rate is allowed to vary according to a preannounced rule. We do not differentiate between these different types of peg or band, including currency board arrangements; in order to concentrate on the big picture we classify them all simply as pegs. It is important to note that occasional adjustments of the level of the exchange rate are permitted under the IMF's definition of a peg. ${ }^{4}$

The alternative classification system that we use is that of Shambaugh (2004). We apply Shambaugh's identification of (actual or potential) anchor currencies to the IMF classification as well. This classification is binary, with a regime defined either as a

\footnotetext{
${ }^{4}$ We are grateful to Harald Anderson of the IMF for supplying the data set.
} 
peg or as a non-peg. Classification as a peg in a given calendar year requires the difference between the maximum and minimum values of the logarithm of the exchange rate against the anchor currency not to exceed 0.04 (or in other words a range of variation that does not exceed $\pm 2 \%$ ), with the single exception that a larger variation is permitted in a single month if the eleven other monthly changes are precisely zero. The resulting peg/non-peg classification is then applied to the entire calendar year. Pegs are somewhat less frequent in the Shambaugh than in the IMF classification, but there exist observations which are pegs according to the IMF and non-pegs according to Shambaugh. ${ }^{5}$

The regime dummies (peg, managed float and independent float) represent the proportion of the time spent in each regime, averaged over the two countries. For example, if country $i$ was a peg for $20 \%$ of the time and a managed float $80 \%$ of the time, while country $j$ was an independent float throughout, the peg dummy for this currency pair would take the value 0.1 , the managed float dummy 0.4 and the independent float dummy 0.5 . We also subdivide the peg dummy by anchor currency.

This specification assumes that the effect on volatility of both countries spending $x \%$ of the time in a given regime is twice that of one country spending $x \%$ of time in that regime. In the case where peg networks are important, this assumption is not justifiable; the currency-stabilizing effects probably require both countries to be pegged to the same anchor. We therefore construct two additional dummies designed

\footnotetext{
${ }^{5}$ Other alternative regime classifications are those of Levy-Yeyati and Sturzenegger (2005) and Reinhart and Rogoff (2004). The former has been criticized for treating big devaluations (e.g. of the CFA franc in 1994) as brief episodes of floating. The latter is unusual in using parallel-market exchange rates; perhaps in part for this reason it is rather an outlier, with a low correlation with other classifications (see Bleaney and Francisco, 2007, and Tavlas et al., 2008, for further discussion).
} 
to differentiate the cases of (a) country $i$ pegging for $2 x \%$ of the time and country $j$ $0 \%$, from (b) both countries pegging $x \%$ of the time. Let the regime dummy for country $i$ have the value $X_{\mathrm{i}}$, and that for country $j X_{\mathrm{j}}$. The two new dummies are respectively:

$$
\begin{aligned}
& B_{i j}=X_{i} X_{j} \\
& E_{i j}=1-\left(1-X_{i}\right)\left(1-X_{j}\right)
\end{aligned}
$$

For $B_{i j}$ to be non-zero requires both $X_{\mathrm{i}}$ and $X_{\mathrm{j}}$ to be non-zero, whereas for $E_{i j}$ to be non-zero requires only one of $X_{\mathrm{i}}$ and $X_{\mathrm{j}}$ to be non-zero. In the simplest case where $X_{\mathrm{i}}$ and $X_{\mathrm{j}}$ are integers, $B_{i j}$ will be one only if both $X_{\mathrm{i}}$ and $X_{\mathrm{j}}$ are one, whereas $E_{i j}$ will be one if either $X_{\mathrm{i}}$ or $X_{\mathrm{j}}$ is one. For this reason we describe $B_{i j}$ as a "Both" dummy and $E_{i j}$ as an "Either" dummy. Note also that

$$
B_{i j}+E_{i j}=X_{i}+X_{j}
$$

Thus the two new regime dummies sum to twice the original dummy, which was equal to $\left(X_{i}+X_{j}\right) / 2$. If $B_{i j}$ and $E_{i j}$ are entered together and emerge with similar coefficients, this is an indication that the original dummy was adequate. ${ }^{6}$ If currency networks are important, then $B_{i j}$ should have a much larger coefficient than $E_{i j}$ for pegs to a particular anchor currency.

\footnotetext{
${ }^{6}$ This is because in this case the implied effect of both being in the given regime, which is the sum of the $B_{i j}$ and $E_{i j}$ coefficients, is approximately twice that of either being in that regime, as assumed in the original dummy.
} 


\section{Currency unions}

In this study the unit of observation is the currency rather than the country, so currency unions are treated as a single unit, with union-level variables calculated as either the sum or the GDP-weighted average of the constituent countries' values, as appropriate.

\section{Episodes of high inflation}

The results that we present exclude all cases where inflation in one of the currency pair exceeds $40 \%$ annually. The regressions are in fact very similar if these observations are included.

\section{$3 \quad$ Empirical Results}

Our data consist of 3415 bilateral exchange rate volatilities for 88 countries. $72 \%$ of the observations relate to pairs of developing countries, $2 \%$ to pairs of industrial countries (following the IMF definition), and the remaining 26\% involve one industrial and one developing country. The mean value of the peg dummy across the whole sample is 0.42 for the IMF classification and 0.31 for the Shambaugh classification. The mean value of the managed float dummy in the IMF classification is 0.28 . Amongst pegs, $80 \%$ are US dollar pegs according to the IMF classification (75\% according to the Shambaugh classification).

Table 1 shows our first results that include control variables and simple regime dummies. Bilateral exchange rate volatility is positively related to land area per capita, cycle asymmetry, economic size and inflation, with the average inflation rate 
being considerably more important than the inflation differential, and negatively correlated with trade. All of these variables are significant at the $1 \%$ level, and their signs are consistent with theory. Volatility is lower if either currency is that of an industrial economy (and even more so if both are), but after allowing for this it is positively correlated with per capita GDP.

In columns (1) and (2) the IMF regime classification is used. Column (1) includes dummies for a peg (to any currency) and a managed float. Both have highly significant negative coefficients, so there is a strong regime effect. These two dummies are both zero only when both currencies are independent floats throughout 1999-2006, which is the implied omitted category. The column (1) estimates imply that volatility is lower by 0.0156 relative to the omitted category when both currencies are pegged, and by 0.0113 when both are managed floats. In column (2) pegs to the US dollar (much the most common anchor currency) are separated from other pegs, and a dummy for the United States being one of the currency pair is also included. It can be seen that the estimated reduction in volatility is much greater for both currencies being pegged to the US dollar $(-0.0123-0.0074)$ than for both being pegged to other currencies $(-0.0074)$. Quite probably this has nothing to do with the US dollar as such, but reflects the size of the US dollar peg network. If a proportion $x$ of currencies is pegged to a given anchor currency, then approximately a fraction $x^{2}$ of all bilateral rates consists of a pair each pegged to that anchor. If the stabilizing effect of pegs derives largely from cases where both currencies are pegged to the same currency, then this quadratic effect means that pegs to commonly chosen anchor currencies will emerge with lower average volatility than pegs to more rarely chosen anchor currencies, other things being equal. 
In columns (3) and (4) of Table 1 we repeat the exercise with the Shambaugh classification. In column (3) the estimated effect of pegging is significantly negative, but less than a third of the size of that for the IMF classification in column (1). Since the Shambaugh classification is binary (peg/non-peg), the omitted category is both currencies being non-pegs, which would include many cases identified in the IMF classification as managed floats. We show in Appendix Table A1 that, if we amend the regressions to have similar omitted categories, the estimated impact of pegging on volatility is similar for the two classifications. In column (4) of Table 1 we separate out US dollar pegs from others. The estimated additional reduction in volatility for US dollar pegs is highly significant and very similar to that estimated in column (2) using the IMF classification (0.0115 compared with 0.0123 in column (2)). 
Table 1. Bilateral Exchange Rate Volatility Regressions with Simple Regime Dummies

\begin{tabular}{|c|c|c|c|c|}
\hline & \multicolumn{2}{|c|}{ IMF Classification } & \multicolumn{2}{|c|}{ JS Classification } \\
\hline & (1) & (2) & (3) & (4) \\
\hline Land Area p.c. & $\begin{array}{c}0.00321 \\
(15.93)^{* * *}\end{array}$ & $\begin{array}{c}0.00344 \\
(17.65)^{* * *}\end{array}$ & $\begin{array}{c}0.00362 \\
(18.39) * * *\end{array}$ & $\begin{array}{c}0.00374 \\
(19.40)^{* * * *}\end{array}$ \\
\hline Trade & $\begin{array}{c}-0.07433 \\
(-4.51)^{* * *}\end{array}$ & $\begin{array}{c}-0.02665 \\
(-2.67)^{* * *}\end{array}$ & $\begin{array}{c}-0.07608 \\
(-4.63) * * *\end{array}$ & $\begin{array}{c}-0.02888 \\
(-2.90)^{* * *}\end{array}$ \\
\hline Cycle Asymmetry & $\begin{array}{c}0.1809 \\
(17.62) * * *\end{array}$ & $\begin{array}{c}0.19211 \\
(18.95)^{* * *}\end{array}$ & $\begin{array}{c}0.19114 \\
(19.22)^{* * * *}\end{array}$ & $\begin{array}{c}0.19855 \\
(20.39)^{* * *}\end{array}$ \\
\hline Size & $\begin{array}{c}0.00071 \\
(8.30)^{* * * *}\end{array}$ & $\begin{array}{c}0.00090 \\
(10.99)^{* * *}\end{array}$ & $\begin{array}{c}0.00115 \\
(14.34)^{* * *}\end{array}$ & $\begin{array}{c}0.00138 \\
(17.62)^{* * *}\end{array}$ \\
\hline Inflation Average & $\begin{array}{c}0.00255 \\
(22.92)^{* * *}\end{array}$ & $\begin{array}{c}0.00260 \\
(24.22)^{* * *}\end{array}$ & $\begin{array}{c}0.00255 \\
(21.26)^{* * *}\end{array}$ & $\begin{array}{c}0.00261 \\
(21.91)^{* * *}\end{array}$ \\
\hline Inflation Differential & $\begin{array}{c}0.00070 \\
(9.41)^{* * *}\end{array}$ & $\begin{array}{c}0.00072 \\
(9.93)^{* * * *}\end{array}$ & $\begin{array}{l}0.00065 \\
(8.09)^{* * *}\end{array}$ & $\begin{array}{c}0.00062 \\
(7.89)^{* * *}\end{array}$ \\
\hline GDP pc & $\begin{array}{c}0.00399 \\
(15.15)^{* * *}\end{array}$ & $\begin{array}{c}0.00387 \\
(15.36)^{* * *}\end{array}$ & $\begin{array}{c}0.00313 \\
(12.56)^{* * *}\end{array}$ & $\begin{array}{c}0.00277 \\
(11.28)^{* * *}\end{array}$ \\
\hline Peg & $\begin{array}{c}-0.01562 \\
(-15.57)^{* * *}\end{array}$ & $\begin{array}{c}-0.00738 \\
(-6.83)^{* * *}\end{array}$ & $\begin{array}{c}-0.00434 \\
(-5.40)^{* * *}\end{array}$ & $\begin{array}{c}0.00416 \\
(3.68)^{* * *}\end{array}$ \\
\hline USD Peg & & $\begin{array}{c}-0.01225 \\
(-13.31)^{* * *}\end{array}$ & & $\begin{array}{c}-0.01148 \\
(-9.42)^{* * *}\end{array}$ \\
\hline United States Dummy & & $\begin{array}{c}-0.01416 \\
(-10.99)^{* * * *}\end{array}$ & & $\begin{array}{c}-0.01485 \\
-(11.13)^{* * *}\end{array}$ \\
\hline Managed Float & $\begin{array}{c}-0.01133 \\
(-10.30) * * *\end{array}$ & $\begin{array}{c}-0.01169 \\
(-10.89) * * *\end{array}$ & & \\
\hline DEV. vs. IND Dummy & $\begin{array}{c}-0.00568 \\
(-8.62)^{* * *}\end{array}$ & $\begin{array}{c}-0.00566 \\
(-9.05)^{* * *}\end{array}$ & $\begin{array}{c}-0.00195 \\
(-3.21)^{* * *}\end{array}$ & $\begin{array}{c}-0.00163 \\
(-2.80) * * *\end{array}$ \\
\hline IND vs. IND Dummy & $\begin{array}{c}-0.01571 \\
(-11.77)^{* * *}\end{array}$ & $\begin{array}{c}-0.01584 \\
(-11.14)^{* * *}\end{array}$ & $\begin{array}{c}-0.00829 \\
(-6.78)^{* * *}\end{array}$ & $\begin{array}{c}-0.00784 \\
(-5.79) * * *\end{array}$ \\
\hline Constant & $\begin{array}{c}-0.03258 \\
(-7.45)^{* * *}\end{array}$ & $\begin{array}{c}-0.04077 \\
(-9.51)^{* * *}\end{array}$ & $\begin{array}{c}-0.05486 \\
(-13.19) * * *\end{array}$ & $\begin{array}{c}-0.06325 \\
(-15.36) * * *\end{array}$ \\
\hline Obs. & 3415 & 3415 & 3415 & 3415 \\
\hline RMSE & 0.0111 & 0.0106 & 0.0114 & 0.0111 \\
\hline $\mathrm{R}^{\wedge} 2$ & 0.57 & 0.6 & 0.54 & 0.56 \\
\hline
\end{tabular}

Notes: The dependent variable is bilateral exchange rate volatility between all currency pairs, as described in equation (2). White heteroscedasticity robust t-statistics are presented in the parentheses. RMSE is the root mean square residual. Asterisks, ***, **, *, denote the significance level at $1 \%, 5 \%$ and $10 \%$ respectively. Members of the same currency unions have been aggregated as single economies. High-inflation observations defined as $>40 \%$ in any year during the sample period have been excluded. The United States Dummy takes the value of one if the US dollar is one of the two currencies. 
In Table 2 we investigate further by relaxing the assumption in Table 1 that the stabilizing effect of both currencies being pegged to the same anchor is twice as large as that of either currency being on a peg. In column (1) of Table 2, we do this for the IMF classification without identifying anchor currencies, and simply separating "Both Pegs" from "Either Peg". The coefficient of Both Pegs (-0.0092) is about $40 \%$ larger than the coefficient of Either Peg $(-0.0068)$, which is suggestive of a currency network effect; but of course many of the Both Pegs identified in column (1) are not pegs to the identical anchor currency. Accordingly in column (2) we separate "Both USD-Pegs" and "Either USD-Peg" from pegs to other anchor currencies. We also include a dummy variable for the United States, since we expect that currencies pegged to the US dollar will have particularly low volatility against that currency. The first point to note about the column (2) results is that, as predicted by the currency network theory, Both USD-Pegs has a much larger coefficient $(-0.01291)$ than Either USD-Peg $(-0.00360)$. This indicates that most of the USD-peg effect derives from cases where both currencies are pegged to the US dollar, which is much the most numerous case of currencies sharing a common anchor. Indeed in column (2) the Both Peg coefficient is now smaller than the Either Peg coefficient, since so many of the cases of a common anchor have been "removed" from this category now that Both USD-Pegs have been separated out.

Columns (3) and (4), in which the Shambaugh regime classification is used, paint a very similar picture. 
Table 2. United States Dollar Peg Networks

\begin{tabular}{|c|c|c|c|c|}
\hline & \multicolumn{2}{|c|}{ IMF Peg Variables } & \multicolumn{2}{|c|}{ JS Peg Variables } \\
\hline & (1) & (2) & (3) & (4) \\
\hline \multirow{2}{*}{ Land Area p.c. } & 0.00320 & 0.00344 & 0.00360 & 0.00373 \\
\hline & $(15.90)^{* * *}$ & $(17.83)^{* * *}$ & $(18.36)^{* * *}$ & $(19.57)^{* * *}$ \\
\hline \multirow{2}{*}{ Trade } & -0.07525 & -0.02591 & -0.07617 & -0.02663 \\
\hline & $(-4.51)^{* * *}$ & $(-2.53) * * *$ & $(-4.59) * * *$ & $(-2.64) * * *$ \\
\hline \multirow{2}{*}{ Cycle Asymmetry } & 0.18124 & 0.19112 & 0.1924 & 0.19891 \\
\hline & $(17.67)^{* * *}$ & $(18.97)^{* * *}$ & $(19.37)^{* * *}$ & $(20.44)^{* * *}$ \\
\hline \multirow{2}{*}{ Size } & 0.00071 & 0.00091 & 0.00115 & 0.00138 \\
\hline & $(8.36)^{* * *}$ & $(11.08)^{* * *}$ & $(14.44) * * *$ & $(17.74)^{* * *}$ \\
\hline \multirow{2}{*}{ Inflation Average } & 0.00255 & 0.00259 & 0.00258 & 0.00263 \\
\hline & $(22.89)^{* * *}$ & $(24.01)^{* * *}$ & $(21.44) * * *$ & $(22.03)^{* * *}$ \\
\hline \multirow{2}{*}{ Inflation Differential } & 0.00070 & 0.00073 & 0.00062 & 0.00060 \\
\hline & $(9.35)^{* * *}$ & $(10.18)^{* * *}$ & $(7.70) * * *$ & $(7.65)^{* * *}$ \\
\hline \multirow{2}{*}{ GDP pc } & 0.00398 & 0.00384 & 0.00313 & 0.00274 \\
\hline & $(15.11)^{* * *}$ & $(15.29)^{* * *}$ & $(12.58) * * *$ & $(11.29)^{* * *}$ \\
\hline \multirow{2}{*}{ Both Pegs } & -0.00924 & -0.00277 & -0.00487 & 0.00330 \\
\hline & $(-11.83)^{* * *}$ & $(-3.73)^{* * *}$ & $(-5.02)^{* * *}$ & $(3.14)^{* * *}$ \\
\hline \multirow{2}{*}{ Either Peg } & -0.00677 & -0.00428 & -0.00097 & 0.00162 \\
\hline & $(-11.04)^{* * *}$ & $(-6.47)^{* * *}$ & $(-1.89)^{*}$ & $(2.47)^{* *}$ \\
\hline \multirow{2}{*}{ Both USD-Pegs } & & -0.01291 & & -0.01445 \\
\hline & & $(-12.95)^{* * *}$ & & $(-10.43)^{* * *}$ \\
\hline \multirow{2}{*}{ Either USD-Peg } & & -0.00360 & & -0.00346 \\
\hline & & $(-6.84)^{* * *}$ & & $(-5.24) * * *$ \\
\hline \multirow{2}{*}{ United States Dummy } & & -0.01417 & & -0.01495 \\
\hline & & $(-10.81)^{* * *}$ & & $(-11.00)^{* * *}$ \\
\hline \multirow{2}{*}{ Managed Float } & -0.01129 & -0.01169 & & \\
\hline & $(-10.28)^{* * *}$ & $(-10.89) * * *$ & & \\
\hline \multirow{2}{*}{ Dev vs. IND Dummy } & -0.0057 & -0.00582 & -0.00195 & -0.0017 \\
\hline & $(-8.66)^{* * *}$ & $(-9.39)^{* * *}$ & $(-3.20)^{* * *}$ & $(-2.94)^{* * *}$ \\
\hline \multirow{2}{*}{ IND vs. IND Dummy } & -0.01544 & -0.01523 & -0.00816 & -0.00735 \\
\hline & $(-11.62) * * *$ & $-(10.70)^{* * *}$ & $(-6.68)^{* * *}$ & $(-5.44)^{* * *}$ \\
\hline \multirow{2}{*}{ Constant } & -0.03321 & -0.04102 & -0.0556 & -0.06341 \\
\hline & $(-7.59) * * *$ & $(-9.55)^{* * *}$ & $(-13.38) * * *$ & $(-15.40)^{* * *}$ \\
\hline Obs. & 3415 & 3415 & 3415 & 3415 \\
\hline RMSE & 0.0110 & 0.0105 & 0.0114 & 0.0110 \\
\hline $\mathrm{R}^{\wedge} 2$ & 0.57 & 0.61 & 0.54 & 0.57 \\
\hline
\end{tabular}

Notes: The dependent variable is bilateral exchange rate volatility between all currency pairs, as described in equation (2). See Notes to Table 1. 
In Table 3 we refine our analysis of non-USD pegs further by identifying all cases where the two currencies are pegged to the same anchor currency. In column (1), where the IMF classification is used, the coefficient of Both Same Non-USD Pegs (0.01819) is very similar to the sum of Both USD-Pegs (-0.01418) and Either USDPeg $(-0.00438)$. This shows that the estimated currency network effect is similar for both the US dollar and other anchor currencies. Column (2) repeats this exercise for the Shambaugh classification. In this case the estimated stabilizing effect of Both Same Non-USD Pegs $(-0.02939)$ is rather larger than that of the sum of Both USDPegs $(-0.01618)$ and Either USD-Peg $(-0.00419)$.

A complication arises here with currencies that have switched exchange rate regime during the period. If the stabilizing effect of exchange rate pegs operates through currency networks, then it requires currencies to peg simultaneously to the same anchor. If currencies A and B have been pegged to the US dollar for half the period, and (say) independently floating for the rest, the value of the Both USD-Pegs dummy will be 0.25 for this currency pair, whatever proportion of the period currencies $\mathrm{A}$ and B were pegged to the US dollar simultaneously (this proportion could be anything between zero and 50\%). Later we present a more refined measure of both currencies having the same anchor that takes this simultaneity factor into account. 
Table 3. All Peg Networks

\begin{tabular}{|c|c|c|}
\hline & $\begin{array}{l}\text { (1) IMF } \\
\text { Classification }\end{array}$ & (2) JS Classification \\
\hline \multirow{2}{*}{ Land Area p.c. } & 0.00333 & 0.00364 \\
\hline & $(17.38)^{* * *}$ & $(19.20)^{* * *}$ \\
\hline \multirow{2}{*}{ Trade } & -0.02143 & -0.02070 \\
\hline & $(-2.31)^{* *}$ & $(-2.26)^{* *}$ \\
\hline \multirow{2}{*}{ Cycle Asymmetry } & 0.19358 & 0.20070 \\
\hline & $(19.46)^{* * *}$ & $(20.83)^{* * *}$ \\
\hline \multirow{2}{*}{ Size } & 0.00096 & 0.00142 \\
\hline & $(11.72)^{* * *}$ & $(18.18)^{* * *}$ \\
\hline \multirow{2}{*}{ Inflation Average } & 0.00268 & 0.00272 \\
\hline & $(24.95)^{* * *}$ & $(22.82)^{* * *}$ \\
\hline \multirow{2}{*}{ Inflation Differential } & 0.00069 & 0.00055 \\
\hline & $(9.55)^{* * *}$ & $(7.02)^{* * * *}$ \\
\hline \multirow{2}{*}{ GDP pc } & 0.00410 & 0.00296 \\
\hline & $(16.29)^{* * *}$ & $(12.06)^{* * *}$ \\
\hline \multirow{2}{*}{ Both Pegs } & -0.00125 & 0.00515 \\
\hline & $(-1.77)^{*}$ & $(5.38)^{* * *}$ \\
\hline \multirow{2}{*}{ Either Peg } & -0.00359 & 0.00248 \\
\hline & $(-5.53)^{* * *}$ & $(3.89)^{* * *}$ \\
\hline \multirow{2}{*}{ Both USD-Pegs } & -0.01418 & -0.01618 \\
\hline & $(-14.42)^{* * *}$ & $(-12.13)^{* * *}$ \\
\hline \multirow{2}{*}{ Either USD-Peg } & -0.00438 & -0.00419 \\
\hline & $(-8.37)^{* * *}$ & $(-6.50)^{* * *}$ \\
\hline \multirow{2}{*}{ Both Same Non-USD Pegs } & -0.01819 & -0.02939 \\
\hline & $(-13.37)^{* * *}$ & $(-11.36)^{* * *}$ \\
\hline \multirow{2}{*}{ United States Dummy } & -0.01190 & -0.01308 \\
\hline & $(-8.35)^{* * *}$ & $(-9.24) * * *$ \\
\hline Either USD-Peg $\mathrm{x}$ & -0.01104 & -0.01262 \\
\hline United States Dummy & $(-4.71)^{* * *}$ & $(-5.16)^{* * *}$ \\
\hline \multirow{2}{*}{ Euro Dummy } & -0.00730 & -0.00633 \\
\hline & $(-6.75)^{* * *}$ & $(-5.75)^{* * *}$ \\
\hline \multirow{2}{*}{ Managed Float } & -0.01173 & \\
\hline & $(-11.02)^{* * *}$ & \\
\hline \multirow{2}{*}{ Dev vs. IND Dummy } & -0.00535 & -0.00123 \\
\hline & $(-8.88)^{* * *}$ & $(-2.18)^{* *}$ \\
\hline \multirow{2}{*}{ IND vs. IND Dummy } & -0.01523 & -0.00720 \\
\hline & $(-11.76)^{* * *}$ & $(-5.81)^{* * *}$ \\
\hline \multirow{2}{*}{ Constant } & -0.04645 & -0.06783 \\
\hline & $(-10.67)^{* * *}$ & $(-16.12)^{* * *}$ \\
\hline Obs. & 3415 & 3415 \\
\hline RMSE & 0.0103 & 0.0109 \\
\hline $\mathrm{R}^{\wedge} 2$ & 0.62 & 0.58 \\
\hline
\end{tabular}

Notes: The dependent variable is bilateral exchange rate volatility between all currency pairs, as described in equation (2). See Notes to Table 1. The Euro Dummies takes the value of one if the euro is one of the two currencies. 


\section{Inflation and peg network effects}

Anchor currencies tend to have low inflation rates. Pegged currencies with significant inflation can be expected to be devalued periodically, whereas those without significant inflation may not be. Because of this, the positive correlation of exchange rate volatility with inflation may be particularly strong for pegs. This would imply that the currency-stabilizing effects of pegs to a common anchor might be significantly eroded by inflation in the currencies concerned. To investigate this, we introduce an interaction term between a dummy for pegs to the same anchor currency and inflation. If inflation erodes the stabilizing effects of a common anchor, this interaction term should have a significant positive coefficient. To simplify the regression further, we replace most of the explanatory variables by double country fixed effects (i.e. fixed effects for both country $i$ and country $j$ ), retaining only those where the variable's value is specific to that country pair. ${ }^{7}$

Table 4 shows the results. Trade and cycle asymmetry have significantly negative and positive coefficients respectively, as in earlier regressions. Column (1) shows the results for the IMF classification. The Both Same Pegs dummy has a coefficient of 0.01455, which represents the estimated stabilizing effect of a common anchor (relative to all other regimes) at zero inflation rates. The interaction term of the Both Same Pegs dummy and average inflation has a significant coefficient of +0.00123 , indicating that inflation does indeed erode the currency-stabilizing effects of a common anchor. Dividing -0.01455 by 0.00123 , we can see that the estimated

\footnotetext{
${ }^{7}$ Variables that are constructed as averages of values for country $i$ and country $j$, with the country $i$ value the same for all pairs that involve country $i$, are collinear with the fixed effects. This applies to all the regime variables except a dummy for pegging to the same anchor, and all the control variables except trade and cycle asymmetry.
} 
stabilizing effects are entirely eliminated once inflation averaged over the currency pair reaches about $12 \%$ per annum.

In column (2) of Table 4, the same regression is repeated for the Shambaugh classification. The results are fairly similar. The Both Same Pegs dummy has a somewhat larger coefficient $(-0.0179)$, but so also does the interaction term $(+0.00193)$, so inflation is estimated to erode the stabilizing effects of common anchors more quickly, reaching zero at an average inflation rate of about $9 \% .^{8}$

In columns (3) and (4) of Table 4, we repeat the analysis with real (CPI-adjusted) exchange rate volatility. The sample is slightly smaller because of the exclusion of a few countries that do not collect consumer price data monthly. In this case the estimated currency-stabilizing effects of common anchors at zero inflation are about $20 \%$ less than for nominal rates in either regime classification, and the interaction term is significantly positive once again.

The results in Table 4 take account only of the average inflation of the currency pair and not of its differential. In Table 5 we also interact the Both Same Pegs dummy with the inflation differential. This has the expected positive coefficient, but the interaction term with average inflation continues to be significant. It seems that both average inflation and the inflation differential have the effect of eroding the currencystabilizing effects of common anchors.

\footnotetext{
${ }^{8}$ Since the identification of anchor currencies is the same for both classifications, the differences derive from disagreements about when currencies were pegged, not what currency they were pegged to.
} 
Table 4. Peg Networks and Inflation: Double Fixed Effect Regressions

\begin{tabular}{|c|c|c|c|c|}
\hline & \multicolumn{2}{|c|}{ Nominal Exchange Rates } & \multicolumn{2}{|c|}{ Real Exchange Rates } \\
\hline & IMF Classification & JS Classification & IMF Classification & JS Classification \\
\hline \multirow{2}{*}{ Trade } & -0.04479 & -0.03975 & -0.04078 & -0.03876 \\
\hline & $(-4.17)^{* * *}$ & $(-3.64) * * *$ & $(-4.37)^{* * *}$ & $(-4.24) * * *$ \\
\hline \multirow{2}{*}{ Cycle Asymmetry } & 0.06260 & 0.06268 & 0.06844 & 0.06814 \\
\hline & $(4.36) * * *$ & $(4.39) * * *$ & $(4.07)^{* * *}$ & $(4.04) * * *$ \\
\hline Av'e Inflation $\mathrm{x}$ & 0.00123 & 0.00193 & 0.00085 & 0.00190 \\
\hline Both Same Pegs & $(7.75)^{* * *}$ & $(6.88) * * *$ & $(3.30) * * *$ & $(6.71)^{* * *}$ \\
\hline \multirow{2}{*}{ Both Same Pegs } & -0.01455 & -0.01794 & -0.01205 & -0.01444 \\
\hline & $(-17.32)^{* * *}$ & $(-17.53) * * *$ & $(-12.06)^{* * *}$ & $(-12.41)^{* * *}$ \\
\hline Obs. & 3415 & 3415 & 2943 & 2943 \\
\hline RMSE & 0.0043 & 0.0043 & 0.0047 & 0.0048 \\
\hline $\mathrm{R}^{\wedge} 2$ & 0.99 & 0.99 & 0.99 & 0.99 \\
\hline
\end{tabular}

Notes: The dependent variable is bilateral exchange rate volatility between all currency pairs, as described in equation (2). See Notes to Table 1. Dummies for both currencies $i$ and $j$ are included in the regressions.

Table 5. Double Fixed Effect Regressions Including Inflation Differentials

\begin{tabular}{|c|c|c|c|c|}
\hline & \multicolumn{2}{|c|}{ Nominal Exchange Rates } & \multicolumn{2}{|c|}{ Real Exchange Rates } \\
\hline & IMF Classification & JS Classification & IMF Classification & JS Classification \\
\hline \multirow{2}{*}{ Trade } & -0.04459 & -0.03955 & -0.04030 & -0.03787 \\
\hline & $(-4.27)^{* * *}$ & $(-3.68) * * *$ & $(-4.32) * * *$ & $(-4.11)^{* * *}$ \\
\hline \multirow{2}{*}{ Cycle Asymmetry } & 0.06334 & 0.06256 & 0.06882 & 0.06866 \\
\hline & $(4.49)^{* * *}$ & $(4.42)^{* * *}$ & $(4.09)^{* * *}$ & $(4.10)^{* * *}$ \\
\hline Av'e Inflation $\mathrm{x}$ & 0.00046 & 0.00113 & 0.00045 & 0.00103 \\
\hline Both Same Pegs & $(1.73)^{*}$ & $(3.48)^{* * *}$ & $(1.81)^{*}$ & $(3.61)^{* * *}$ \\
\hline Inflation Differential $\mathrm{x}$ & 0.00064 & 0.00118 & 0.00035 & 0.00150 \\
\hline Both Same Pegs & $(4.22)^{* * *}$ & $(5.10)^{* * *}$ & $(1.21)$ & $(4.94)^{* * *}$ \\
\hline \multirow{2}{*}{ Both Same Pegs } & -0.01467 & -0.01974 & -0.01215 & -0.01713 \\
\hline & $(-17.89)^{* * *}$ & $(-18.41)^{* * *}$ & $(-11.74)^{* * *}$ & $(-13.03)^{* * *}$ \\
\hline Obs. & 3415 & 3415 & 2943 & 2943 \\
\hline RMSE & 0.0043 & 0.0043 & 0.0047 & 0.0047 \\
\hline $\mathrm{R}^{\wedge} 2$ & 0.99 & 0.99 & 0.99 & 0.99 \\
\hline
\end{tabular}

Notes: The dependent variable is bilateral exchange rate volatility between all currency pairs, as described in equation (2). See Notes to Table 1. Dummies for both currencies $i$ and $j$ are included in the regressions. 


\section{Managed floats}

It has been suggested that managed floats are so heavily managed that they are quasipegs (Calvo and Reinhart, 2002). Our results so far suggest that managed floats have considerably less exchange rate volatility than independent floats. A further interesting question is: if managed floats are quasi-pegs, to what anchor currency? In Table 6 we include dummies for every possible pair of regimes in the IMF classification (the omitted category being both independent floats) to investigate this issue. In this Table a variable described as "regime $\mathrm{X}$ with regime $\mathrm{Y}$ " is generated by the following formula:

$$
(X w i t h Y)_{i j}=X_{i} Y_{j}+Y_{j} X_{i}
$$

This variable will be one if country $i$ was in regime $X 100 \%$ of the time and country $j$ was in regime $Y 100 \%$ of the time, or vice versa.

The first column of Table 6 shows the results. All regimes display significantly lower volatility than the omitted category of Both Independent Floats. The lowest volatility is associated with Both USD-Pegs $(-0.0215)$, but for Both Same Non-USD Pegs the estimated coefficient is very similar $(-0.0210) .{ }^{9}$ This suggests that the effect on bilateral exchange rate volatility of pegging to a common anchor is similar across anchor currencies, as one might expect. Managed Floats have much lower volatility with USD-Pegs $(-0.0142)$ than with Non-USD Pegs $(-0.0060),{ }^{10}$ for which volatility is greater than in the case of Both Managed Floats $(-0.0095)$.

\footnotetext{
${ }^{9}$ The two coefficients are not significantly different: $\mathrm{F}(1,3393)=0.10[p=0.75]$.

${ }^{10}$ The difference is statistically significant: $\mathrm{F}(1,3393)=80.0[p<0.0001]$.
} 
The dummy for the United States has a significant negative coefficient of -0.0661 , which indicates that all currencies tend to be more stable against the US dollar, after controlling for other factors. As one would expect, this effect is particularly strong for USD-Pegs (the US dummy interacted with the USD Peg dummy has a coefficient of -0.01675 ), but it is also significant for Managed Floats (the US dummy interacted with the Managed Float dummy has a significant coefficient of -0.00986 , which represents the estimated extra stabilizing effect against the US dollar of being a managed float rather than an independent float or a non-USD peg).

The greater stability of managed floats against the US dollar, and against other currencies that are pegged to the US dollar, than against non-USD pegs suggests strongly that managed floats tend to track the US dollar, and that in many cases they can be regarded effectively as members of the US dollar network. This increases the effective size of the network and also the attractiveness of pegging or quasi-pegging to the US dollar, relative to other regimes. 
Table 6. Exchange Rate Volatility and Managed Floats

\begin{tabular}{|c|c|c|}
\hline & Approximated Frequencies & Exact Frequencies \\
\hline Land Area p.c. & $\begin{array}{c}0.00344 \\
(18.04)^{* * *}\end{array}$ & $\begin{array}{c}0.00345 \\
(18.05)^{* * *}\end{array}$ \\
\hline Trade & $\begin{array}{l}-0.01926 \\
(-2.03)^{* *}\end{array}$ & $\begin{array}{l}-0.01912 \\
(-2.01)^{* *}\end{array}$ \\
\hline Cycle Asymmetry & $\begin{array}{c}0.19119 \\
(19.15)^{* * *}\end{array}$ & $\begin{array}{c}0.19106 \\
(19.15)^{* * *}\end{array}$ \\
\hline Size & $\begin{array}{c}0.00092 \\
(11.30)^{* * *}\end{array}$ & $\begin{array}{c}0.00091 \\
(11.28)^{* * *}\end{array}$ \\
\hline Inflation Average & $\begin{array}{c}0.00260 \\
(24.36) * * *\end{array}$ & $\begin{array}{c}0.00260 \\
(24.29) * * *\end{array}$ \\
\hline Inflation Differential & $\begin{array}{c}0.00072 \\
(10.02)^{* * *}\end{array}$ & $\begin{array}{c}0.00072 \\
(10.06)^{* * *}\end{array}$ \\
\hline GDP pc & $\begin{array}{c}0.00384 \\
(15.46)^{* * *}\end{array}$ & $\begin{array}{c}0.00384 \\
(15.45)^{* * *}\end{array}$ \\
\hline Both USD Pegs & $\begin{array}{c}-0.02147 \\
(-16.83)^{* * *}\end{array}$ & $\begin{array}{c}-0.02140 \\
(-16.81)^{* * *}\end{array}$ \\
\hline Both Same Non-USD Pegs & $\begin{array}{c}-0.02101 \\
(-14.45)^{* * *}\end{array}$ & $\begin{array}{c}-0.02106 \\
(-14.58) * * *\end{array}$ \\
\hline Pegs to Different Anchors & $\begin{array}{l}-0.00710 \\
(-6.62)^{* * *}\end{array}$ & $\begin{array}{l}-0.00710 \\
(-6.65)^{* * *}\end{array}$ \\
\hline $\begin{array}{l}\text { USD Peg with } \\
\text { Managed Float }\end{array}$ & $\begin{array}{c}-0.01416 \\
(-12.68) * * *\end{array}$ & $\begin{array}{c}-0.01439 \\
(-13.03)^{* * *}\end{array}$ \\
\hline Non-USD Peg with & -0.00595 & -0.00616 \\
\hline Managed Float & $(-5.25)^{* * *}$ & $(-5.48) * * *$ \\
\hline USD Peg with & -0.00489 & -0.00499 \\
\hline Independent Float & $(-5.11)^{* * *}$ & $(-5.28) * * *$ \\
\hline $\begin{array}{l}\text { Non-USD Peg } \\
\text { with Independent Float }\end{array}$ & $\begin{array}{c}-0.00349 \\
(-3.31)^{* * *}\end{array}$ & $\begin{array}{l}-0.00350 \\
(-3.37)^{* * *}\end{array}$ \\
\hline Both Managed Floats & $\begin{array}{l}-0.00945 \\
(-7.01)^{* * *}\end{array}$ & $\begin{array}{l}-0.00921 \\
(-6.84)^{* * *}\end{array}$ \\
\hline Managed Float with & -0.00372 & -0.00384 \\
\hline Independent Float & $(-3.42)^{* * *}$ & $(-3.64) * * *$ \\
\hline United States Dummy & $\begin{array}{c}-0.00676 \\
(-4.24) * * *\end{array}$ & $\begin{array}{l}-0.00680 \\
(-4.26)^{* * *}\end{array}$ \\
\hline USD Peg $\mathrm{x}$ & -0.01639 & -0.01634 \\
\hline United States Dummy & $(-6.44)^{* * *}$ & $(-6.41)^{* * *}$ \\
\hline Managed Float x & -0.00946 & -0.00937 \\
\hline United States Dummy & $(-2.89) * * *$ & $(-2.87)^{* * *}$ \\
\hline DEV. vs. IND Dummy & $\begin{array}{l}-0.00587 \\
(-9.55)^{* * *}\end{array}$ & $\begin{array}{l}-0.00586 \\
(-9.54) * * *\end{array}$ \\
\hline IND vs. IND Dummy & $\begin{array}{c}-0.01511 \\
(-11.01)^{* * * *}\end{array}$ & $\begin{array}{c}-0.01516 \\
(-11.06)^{* * *}\end{array}$ \\
\hline Constant & $\begin{array}{c}-0.04318 \\
(-9.99) * * *\end{array}$ & $\begin{array}{l}-0.04297 \\
(-9.95) * * *\end{array}$ \\
\hline Obs. & 3415 & 3415 \\
\hline RMSE & 0.0103 & 0.0103 \\
\hline $\mathrm{R}^{\wedge} 2$ & 0.62 & 0.62 \\
\hline
\end{tabular}

Notes: See Notes to Table 1. IMF regime classifications are used. "Pegs to Different Anchors" = Both Pegs - Both USD Pegs - Both Same Non-USD Pegs. 
As mentioned earlier, the "Both" dummies may be inaccurately measured where countries have switched regime during the sample period, since they take no account of how often currencies were simultaneously pegged to the same anchor. In column (2) of Table 6, we repeat the regression of column (1) with a more accurate measure of simultaneity. Instead of taking the proportion of the period 1999-2006 that currencies are in a given regime, and then multiplying these proportions, as shown in equation (3), we reverse the order and multiply the two regime dummies for countries $i$ and $j$ for each quarter, and then average those values. In this second method, the "Both" dummy will reflect only the proportion of quarters in which currencies are simultaneously in the same regime. Column (2) of Table 6 shows the results. They are very similar indeed to column (1), so the potential inaccuracy of the approximated frequencies is not a concern in practice.

\section{Endogeneity issues}

There is a potential concern that some of the explanatory variables may be endogenous to volatility itself. For example there has been considerable research on whether exchange rate volatility discourages trade (e.g. Clark et al., 2004), mostly with rather mixed results. If volatility affects output, it could have an impact on the measure of cycle asymmetry. Although these concerns are almost certainly exaggerated, ${ }^{11}$ in Table 7 we show a Two-Stage Least Squares (2SLS) version of the Table 6 regression, with trade and cycle asymmetry instrumented by variables such as distance, dummies for a common language, a past colonial relationship and landlockedness, etc.

\footnotetext{
${ }^{11}$ The variation in trade flows across the sample is so vast that even a $10 \%$ reduction, say, in one country pair because of exchange rate volatility will have a negligible effect on the overall picture.
} 
Table7. Two-Stage Least Squares (Trade and Cycle Asymmetry $=$ Endogenous Variables)

\begin{tabular}{|c|c|c|c|}
\hline Trade & $\begin{array}{c}-0.13876 \\
(-3.10)^{* * *}\end{array}$ & Both USD Pegs & $\begin{array}{c}-0.01783 \\
(-8.94)^{* * *}\end{array}$ \\
\hline \multirow{4}{*}{ Cycle Asymmetry } & 0.51850 & \multirow{2}{*}{$\begin{array}{l}\text { Both Same } \\
\text { Non-USD Pegs }\end{array}$} & -0.01703 \\
\hline & $(5.34)^{* * *}$ & & $(-6.40) * * *$ \\
\hline & & \multirow{2}{*}{$\begin{array}{l}\text { Pegs to Different } \\
\text { Anchors }\end{array}$} & -0.00269 \\
\hline & & & $(-1.27)$ \\
\hline \multirow{2}{*}{\multicolumn{2}{|c|}{ Other Control Variables }} & \multirow{2}{*}{$\begin{array}{l}\text { USD Peg with } \\
\text { Managed Float }\end{array}$} & -0.01014 \\
\hline & & & $(-5.33)^{* * *}$ \\
\hline \multirow{2}{*}{ Land Area p.c. } & 0.00300 & \multirow{2}{*}{$\begin{array}{l}\text { Non-USD Peg with } \\
\text { Managed Float }\end{array}$} & -0.00132 \\
\hline & $(12.38)^{* * *}$ & & $(-0.62)$ \\
\hline \multirow{2}{*}{ Size } & 0.00147 & \multirow{2}{*}{$\begin{array}{l}\text { USD Peg with } \\
\text { Independent Float }\end{array}$} & -0.00287 \\
\hline & $(9.15)^{* * *}$ & & $(-1.84)^{*}$ \\
\hline \multirow{2}{*}{ Inflation Average } & 0.00276 & \multirow{2}{*}{$\begin{array}{l}\text { Non-USD Peg with } \\
\text { Independent Float }\end{array}$} & -0.00028 \\
\hline & $(19.27)^{* * *}$ & & $(-0.14)$ \\
\hline \multirow{2}{*}{ Inflation Differential } & 0.00016 & \multirow{2}{*}{ Both Managed Floats } & -0.00618 \\
\hline & $(0.87)$ & & $(-3.13)^{* * *}$ \\
\hline \multirow{2}{*}{ GDP pc } & 0.00406 & \multirow{2}{*}{$\begin{array}{l}\text { Managed Float with } \\
\text { Independent Float }\end{array}$} & -0.00155 \\
\hline & $(12.93)^{* * *}$ & & $(-0.87)$ \\
\hline \multirow{2}{*}{ DEV. vs. IND Dummy } & -0.00290 & \multirow{2}{*}{ United States Dummy } & -0.00474 \\
\hline & $(-2.57)^{* *}$ & & $(-1.83)^{*}$ \\
\hline \multirow{2}{*}{ IND vs. IND Dummy } & -0.00770 & \multirow{2}{*}{$\begin{array}{l}\text { USD Peg x } \\
\text { United States Dummy }\end{array}$} & -0.01211 \\
\hline & $(-2.99)^{* * *}$ & & $(-3.74) * * *$ \\
\hline \multirow{2}{*}{ Constant } & -0.08768 & Managed Float x & -0.00882 \\
\hline & $(-7.43)^{* * *}$ & United States Dummy & $(-2.07)^{* *}$ \\
\hline \multicolumn{2}{|c|}{ Obs. } & \multicolumn{2}{|c|}{3330} \\
\hline \multicolumn{2}{|c|}{$\mathrm{R}^{\wedge} 2$} & \multicolumn{2}{|c|}{0.45} \\
\hline \multicolumn{2}{|c|}{ RMSE } & \multicolumn{2}{|c|}{0.0125} \\
\hline
\end{tabular}

Notes: See Notes to Table 1. IMF regime classifications are used. "Pegs to Different Anchors" = Both Pegs - Both USD Pegs - Both Same Non-USD Pegs. 
It can be seen from Table 7 that this does not change the picture with respect to regime effects. Pegs to the same anchor currency (the US dollar or otherwise) have the lowest volatility, followed by USD Pegs against Managed Floats, and Both Managed Floats, as in Table 6.

\section{Basket pegs}

A few countries are classified by the IMF as basket pegs (see Appendix Table A2 for a list). Hitherto we have treated these countries as pegged to the anchor identified by Shambaugh (2004) rather than as basket pegs. In Table 8 we treat basket pegs as a separate category. The new basket peg variables are jointly significant, ${ }^{12}$ but their inclusion does not change the other coefficients to any significant degree. Basket pegs display similar volatility against US Dollar Pegs (-0.00890) and Non-USD pegs $(-0.01034) .{ }^{13}$ They are more volatile against each other $(-0.01383)$ than are Both US Dollar Pegs $(-0.02415)$ or Both Same Non-USD Pegs $(-0.02278)$, which is to be expected because the baskets used by different countries are not identical.

\footnotetext{
${ }^{12} \mathrm{~F}(5,3387)=16.64[p<0.0001]$.

${ }^{13} \mathrm{~F}(1,3387)=0.55[p=0.457]$.
} 


\begin{tabular}{|c|c|c|c|}
\hline \multicolumn{4}{|c|}{ Control Variables } \\
\hline Land Area p.c. & $\begin{array}{c}0.00341 \\
(18.00)^{* * *}\end{array}$ & Trade & $\begin{array}{c}-0.01484 \\
(-1.57)\end{array}$ \\
\hline Size & $\begin{array}{c}0.00100 \\
(12.13)^{* * *}\end{array}$ & Cycle Asymmetry & $\begin{array}{c}0.19040 \\
(18.99)^{* * * *}\end{array}$ \\
\hline Inflation Average & $\begin{array}{c}0.00265 \\
(24.93)^{* * *}\end{array}$ & GDP pc & $\begin{array}{c}0.00381 \\
(15.40)^{* * *}\end{array}$ \\
\hline Inflation Differential & $\begin{array}{c}0.00073 \\
(10.19)^{* * *}\end{array}$ & & \\
\hline \multicolumn{4}{|c|}{ Regime Variables } \\
\hline Both USD Pegs & $\begin{array}{c}-0.02415 \\
(-18.50) * * *\end{array}$ & Both Basket Pegs & $\begin{array}{c}-0.01383 \\
(-6.86) * * *\end{array}$ \\
\hline Both Same Non-USD Pegs & $\begin{array}{c}-0.02278 \\
(-12.48)^{* * *}\end{array}$ & $\begin{array}{l}\text { USD Peg with } \\
\text { Basket Pegs }\end{array}$ & $\begin{array}{l}-0.00890 \\
(-6.96)^{* * *}\end{array}$ \\
\hline Pegs to Different Anchors & $\begin{array}{c}-0.00551 \\
(-4.76)^{* * *}\end{array}$ & $\begin{array}{l}\text { Non-USD Peg with } \\
\text { Basket Pegs }\end{array}$ & $\begin{array}{c}-0.01034 \\
(-6.85)^{* * *}\end{array}$ \\
\hline $\begin{array}{l}\text { USD Peg with } \\
\text { Managed Float }\end{array}$ & $\begin{array}{c}-0.01461 \\
(-12.77)^{* * *}\end{array}$ & $\begin{array}{l}\text { Managed Float with } \\
\text { Basket Pegs }\end{array}$ & $\begin{array}{c}-0.00816 \\
(-6.01)^{* * *}\end{array}$ \\
\hline $\begin{array}{l}\text { Non-USD Peg with } \\
\text { Managed Float }\end{array}$ & $\begin{array}{l}-0.00520 \\
(-4.30)^{* * *}\end{array}$ & $\begin{array}{l}\text { Independent Float with } \\
\text { Basket Pegs }\end{array}$ & $\begin{array}{l}-0.00485 \\
(-3.98) * * *\end{array}$ \\
\hline $\begin{array}{l}\text { USD Peg with } \\
\text { Independent Float }\end{array}$ & $\begin{array}{c}-0.00476 \\
(-4.86)^{* * *}\end{array}$ & Both Managed Floats & $\begin{array}{l}-0.00947 \\
(-7.01)^{* * *}\end{array}$ \\
\hline $\begin{array}{l}\text { Non-USD Peg with } \\
\text { Independent Float }\end{array}$ & $\begin{array}{l}-0.00246 \\
(-2.13)^{* *}\end{array}$ & $\begin{array}{l}\text { Managed Float with } \\
\text { Independent Float }\end{array}$ & $\begin{array}{c}-0.00376 \\
(-3.46)^{* * *}\end{array}$ \\
\hline United States Dummy & $\begin{array}{c}-0.00680 \\
(-3.95)^{* * *}\end{array}$ & $\begin{array}{l}\text { Basket Pegs x } \\
\text { United States Dummy }\end{array}$ & $\begin{array}{c}-0.00273 \\
(-1.13)\end{array}$ \\
\hline $\begin{array}{l}\text { USD Peg x } \\
\text { United States Dummy }\end{array}$ & $\begin{array}{l}-0.01865 \\
(-7.11)^{* * *}\end{array}$ & $\begin{array}{l}\text { Managed Float x } \\
\text { United States Dummy }\end{array}$ & $\begin{array}{c}-0.00967 \\
(-2.87) * * *\end{array}$ \\
\hline IND vs. IND Dummy & $\begin{array}{c}-0.00607 \\
(-9.90) * * *\end{array}$ & & \\
\hline DEV vs. IND Dummy & $\begin{array}{c}-0.01555 \\
(-11.28) * * *\end{array}$ & & \\
\hline Constant & $\begin{array}{c}-0.04759 \\
(-10.76)^{* * *} \\
\end{array}$ & & \\
\hline Obs. & & 3415 & \\
\hline $\mathrm{R}^{\wedge} 2$ & & 0.63 & \\
\hline RMSE & & 0.0102 & \\
\hline
\end{tabular}

Notes: See Notes to Table 1. IMF regime classifications are used. "Pegs to Different Anchors" = Both Pegs - Both USD Pegs - Both Same Non-USD Pegs. 


\section{Multilateral volatility}

If countries choose an exchange rate regime other than an independent float, they presumably do so with the intention of reducing some measure of multilateral exchange rate volatility. We would expect that members of large peg networks would have the largest unweighted average multilateral volatility, because any randomly chosen currency is more likely to be a member of the same peg network. If countries choose their anchors to minimize trade-weighted exchange rate volatility, however, this network size effect should disappear: countries will choose a small peg network only if their trade is particularly weighted towards the members of this network, so their trade-weighted multilateral volatility would not necessarily be greater than that of members of large peg networks. A peg network size effect that is apparent in unweighted multilateral volatility but not in trade-weighted volatility would thus constitute indirect evidence that anchor currencies are indeed chosen by this criterion.

Table 9 shows the results of regressing unweighted and weighted multilateral volatility for 97 currencies on regime dummies and control variables. ${ }^{14}$ Unweighted volatility for currency $i$ is measured as the $\log$ standard deviation over all months of the mean of bilateral monthly nominal exchange rate movements against all other currencies:

$$
U M V_{i}=\ln \left\{\operatorname{STDEV}\left(M E A N_{j}\left(d \ln Z_{i j}\right)\right)\right\}
$$

\footnotetext{
${ }^{14}$ There are a few more currencies than in the bilateral sample because some with less than complete trade data have been included.
} 
and trade-weighted volatility is the trade-weighted equivalent, where $w_{i j}$ represents the value of trade between currencies $i$ and $j$ in 2002, divided by currency $i$ 's 2002 trade with all currencies in the sample:

$$
W M V_{i}=\ln \left\{\operatorname{STDEV}\left(\sum_{j} w_{i j} d \ln Z_{i j}\right)\right\}
$$

The dummy for a peg is multiplied by the size of the peg network, which is equal to the number of participating countries minus the minimum of two. Thus the regime dummies are all equal to zero only for the case of a peg network consisting of only two countries.

The results in Table 9 show that multilateral volatility increases with inflation and land area, and with economic size, but with industrial countries having significantly lower volatility. As predicted, unweighted volatility decreases with the size of the peg network, in both the IMF and Shambaugh classifications. The managed float and independent float dummies (or the non-peg dummy) are not significant, indicating that these regimes have similar unweighted volatility to small peg networks. With trade-weighted volatility, however, the picture is quite different. The peg network effect is now insignificant, and the non-peg regime dummies are significantly positive. This suggests that countries choose their anchors to minimize tradeweighted exchange rate volatility, and that they achieve greater exchange rate stability by doing so. 
Table 9. Multilateral Exchange Rate Volatility

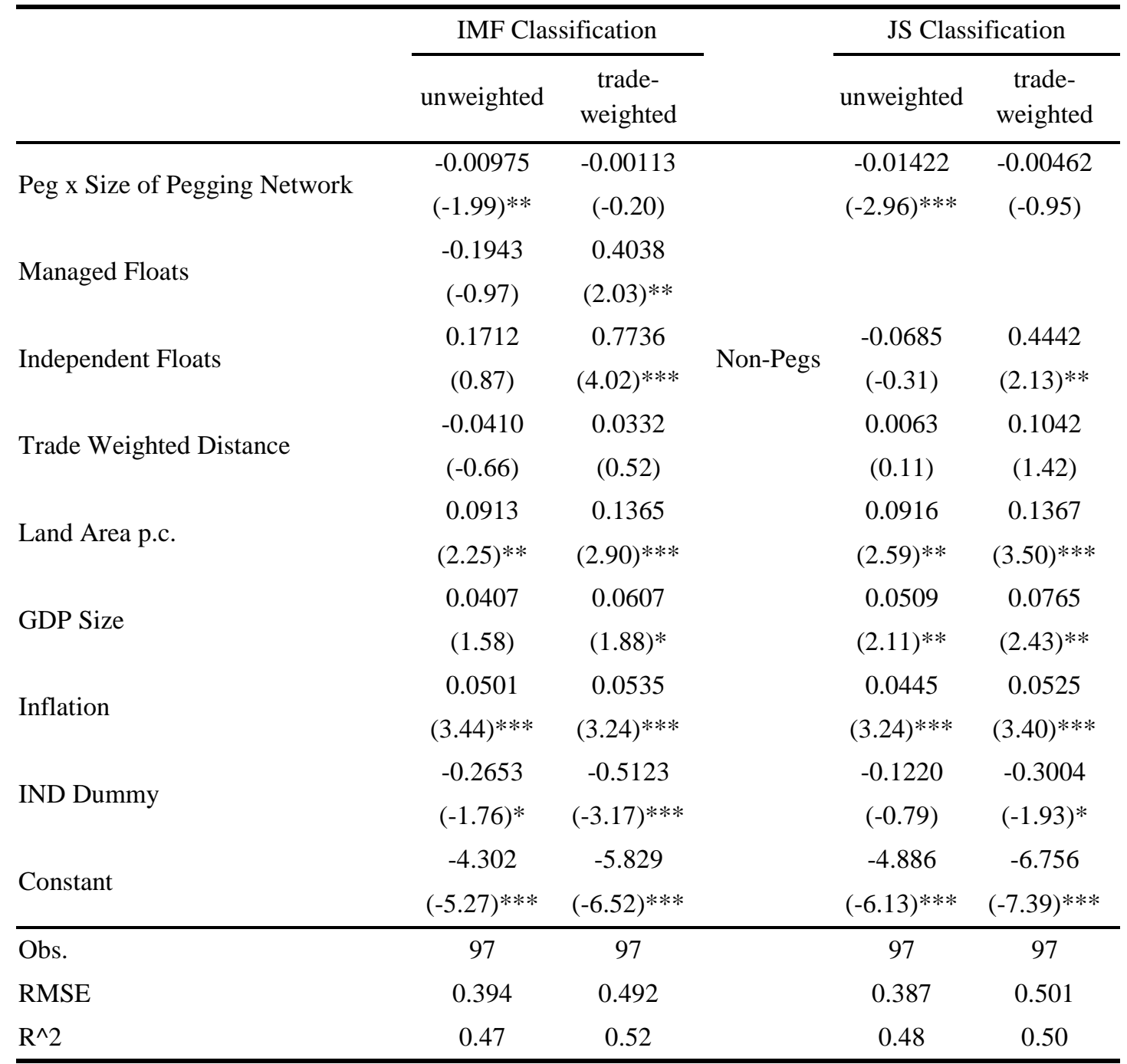

Note: The dependent variables are $U M V$ (unweighted volatility) and $W M V$ (trade-weighted volatility) as given in equations (7) and (8) of the text. "Size of Pegging Network" = number of countries in network minus two. White heteroscedasticity robust t-statistics are presented in the parentheses. RMSE is the Root MSE of the regression. Asterisks, ***, **, *, denote the significance level at $1 \%$, $5 \%$ and $10 \%$ respectively. Members of the same currency unions have been aggregated as single economies. High-inflation observations defined as $>40 \%$ in any year during the sample period have been excluded. 
Table 9 does not tell us whether the size of a peg network affects the choice of anchor. If it does, one would expect small peg networks to be preferred to large ones only if the reasons are compelling. Countries would peg to the euro (the second largest network) rather than the US dollar only if their trade with the Euro Area was very large relative to their trade with the US. This seems to be the case. In 2002 the countries pegged to the euro had total trade with the Euro Area that was 8.08 times larger than their trade with the US, whereas countries pegged to the US dollar had total trade with the US that was only 1.16 times their trade with the Euro Area.

\section{Conclusions}

Once we control for structural factors, whether and to what anchor a currency is pegged matters for exchange rate volatility against other currencies. The US dollar is much the most popular anchor currency, and currencies pegged to the US dollar have significantly lower volatility against each other than against currencies that are not pegged or that are pegged to other anchors. This network effect applies to other currencies as well, such as the euro, but the number of cases is much smaller. Although membership of a small peg network implies higher volatility against any randomly chosen currency than does membership of a large peg network, tradeweighted (as opposed to unweighted) multilateral volatility does not fall with the size of the peg network. This is consistent with the finding of Meissner and Oomes (2009) that countries tend to choose anchors on the basis of the volume of trade with that currency network. The peg network effect is apparent in the very high ratio of bilateral trade with the Euro Area relative to the United States that seems to be required to attract a currency into the euro network. 
In addition to this, managed floats have lower volatility against the US dollar and currencies pegged to it than against independent floats or pegs to other currencies, which is consistent with the idea that floats are managed in part to enjoy the benefits of the US dollar currency network, by deliberately controlling the volatility of the US dollar exchange rate. To a significant degree, the US dollar appears to act as a quasianchor for managed floats, so the effective US dollar currency network is larger than appears at first sight.

This currency network effect may help to explain the rarity of basket pegs. A priori a basket peg would appear to be the optimal way to minimize the volatility of the effective exchange rate, but a single-currency peg might have countervailing advantages, such as greater transparency. If there is an anchor currency that is the centre of a large peg network, pegging to that currency will reduce volatility against many other currencies, and the stabilization gain from choosing a basket peg rather than a peg to that currency will be correspondingly smaller. Consequently fewer countries will choose a basket peg if there exists a large single-currency peg network as an alternative. One can imagine multiple equilibria, in which either most pegs are basket pegs, or most pegs are to the same single currency. The historical role of the US dollar as the universal anchor in the Bretton Woods system might explain why the single-currency equilibrium is the one that we observe. This is of course relevant to the declining status of the US dollar, because it suggests that its role as the centre of a currency network may well survive substantial portfolio diversification of foreign exchange reserves into other currencies. 
If a country has a significant inflation differential relative to its anchor currency, pegging is likely to require periodic parity adjustments. We have shown that the stabilizing effects of currency networks are indeed undermined by inflation in the currencies concerned. According to our results, once inflation averages $10 \%$ p.a. in the pair of countries, most of the stabilizing effects of currency networks are lost, particularly if the inflation rates in the two countries are unequal.

Finally, structural factors are important in bilateral exchange rate volatility. If on average the pair of countries has: low population density (which suggests a specialization in natural resources); a large economic mass; little bilateral trade; more business cycle asymmetry; and higher and less equal inflation rates; then the exchange rate between these currencies will be more volatile. Volatility is also lower if one (or especially if both) of the countries is an advanced country. To a significant degree, therefore, a country has to live with the exchange rate volatility that it gets, although these results show that a sound monetary policy clearly helps.

\section{References}

Bayoumi, T. and B. Eichengreen (1998) Exchange rate volatility and intervention: implications of the theory of optimum currency areas, Journal of International Economics 45, 191-209

Bergin, P. R., R. Glick and A. M. Taylor (2006) Productivity, tradability, and the long-run price puzzle, Journal of Monetary Economics, 53 (8), pp 2041-2066

Bleaney, M.F. (2008) Openness and real exchange rate volatility: in search of an explanation, Open Economies Review 19, 135-146

Bleaney, M.F. and M. Francisco (2005) Exchange rate regimes and inflation: only hard pegs make a difference, Canadian Journal of Economics 38, 1453-71 
Bleaney, M.F. and M. Francisco (2007) Classifying exchange rate regimes: a statistical analysis of alternative methods, Economics Bulletin 6 (3), 1-6

Bleaney, M.F. and M. Francisco (20010) What makes currencies volatile? An empirical investigation, Open Economies Review 21, 731-750

Bravo-Ortega, C. and J. di Giovanni (2005) Trade costs and real exchange rate volatility: the role of Ricardian comparative advantage, IMF Working Paper no. $05 / 5$

Bravo-Ortega, C. and J. di Giovanni (2006) Remoteness and real exchange rate volatility, IMF Staff Papers 53 (Special Issue), 115-132

Broda, C. (2004) Terms of trade and exchange rate regimes in developing countries, Journal of International Economics 63, 31-58

Calvo, G. and C.M. Reinhart (2002) Fear of floating, Quarterly Journal of Economics 117, 379-408

Choudhri, E. U. and M. S. Khan (2005) Real exchange rates in eeveloping countries: are Balassa-Samuelson effects present? IMF Staff Papers, 52 (3)

Clark, P., N. Tamirisa and S.-J. Wei (2004) A new look at exchange rate volatility and trade flows, International Monetary Fund, Occasional Paper no. 235

Devereux, M.B. and P. Lane (2003) Understanding bilateral exchange rate volatility, Journal of International Economics 60, 109-132

Edwards, S. and E. Levy-Yeyati (2005) Flexible Exchange Rates as shock absorbers, European Economic Review, 49, 2079-2105

Flood, R.P. and A.K. Rose (1995) Fixing exchange rates: a virtual quest for fundamentals, Journal of Monetary Economics 36, 3-37

Hau, H. (2002) Real exchange rate volatility and openness: theory and evidence, Journal of Money Credit and Banking 34, 611-630

Klein, M.W. and J.C. Shambaugh (2008) The dynamics of exchange rate regimes: fixes, floats and flips, Journal of Internatonal Economics 75, 70-92

Levy-Yeyati, E., and F. Sturzenegger (2005) Classifying exchange rate regimes: deeds versus words, European Economic Review 49, 1603-35

Meissner, C.M. and N. Oomes (2009) Why do countries peg the way they peg? The determinants of anchor currency choice, Journal of International Money and Finance 28 (3), 522-547

Reinhart, C.M. and K. Rogoff (2004) The modern history of exchange rate arrangements: a reinterpretation, Quarterly Journal of Economics 119, 1-48 
Shambaugh, J. (2004) The effect of fixed exchange rates on monetary policy, Quarterly Journal of Economics 119, 301-52

Tavlas, G., H. Dellas and A.C. Stockman (2008) The classification and performance of alternative exchange-rate systems, European Economic Review $52,941-63$

\section{Appendix}

Table A1 shows a version of Table 1 with the regression for the Shambaugh classification amended to have a similar omitted regime category (independent floats) to that of the IMF classification. The apparent anomaly that appeared in column (4) of Table 1 - that with the JS classification pegs other than to the US dollar seemed to have higher volatility than non-pegs, since the Peg dummy had a significant positive coefficient - has now disappeared. In column (2) of Table A1 the Peg dummy has a significant negative coefficient, as in column (1). This is because pegs are now being compared to independent floats as defined in the IMF classification, and not to all non-pegs as defined in the JS classification. 
Table A1. Comparison between IMF and JS Classifications with Similar Reference Category

\begin{tabular}{|c|c|c|c|}
\hline & (1) IMF & & (2) JS \\
\hline \multirow{2}{*}{ Land Area p.c. } & 0.00344 & & 0.00353 \\
\hline & $(17.65)^{* * *}$ & & $(17.57)^{* * *}$ \\
\hline \multirow{2}{*}{ Trade } & -0.02665 & & -0.02739 \\
\hline & $(-2.67)^{* * *}$ & & $(-2.77)^{* * *}$ \\
\hline \multirow{2}{*}{ Cycle Asymmetry } & 0.19211 & & 0.19487 \\
\hline & $(18.95)^{* * *}$ & & $(19.08) * * *$ \\
\hline \multirow{2}{*}{ Size } & 0.0009 & & 0.00114 \\
\hline & $(10.99) * * *$ & & $(13.55)^{* * *}$ \\
\hline \multirow{2}{*}{ Inflation Average } & 0.0026 & & 0.00270 \\
\hline & $(24.22)^{* * *}$ & & $(23.42)^{* * *}$ \\
\hline \multirow{2}{*}{ Inflation Differential } & 0.00072 & & 0.00063 \\
\hline & $(9.93) * * *$ & & $(8.28)^{* * *}$ \\
\hline \multirow{2}{*}{ GDP pc } & 0.00387 & & 0.00308 \\
\hline & $(15.36)^{* * *}$ & & $(11.90)^{* * *}$ \\
\hline \multirow{2}{*}{ Peg } & -0.00738 & & -0.00560 \\
\hline & $(-6.83)^{* * *}$ & & $(-3.22)^{* * *}$ \\
\hline \multirow{2}{*}{ USD Peg } & -0.01225 & & -0.01148 \\
\hline & $(-13.31) * * *$ & & $(-9.24) * * *$ \\
\hline \multirow{3}{*}{ United States Dummy } & -0.01416 & & -0.01455 \\
\hline & $(-10.99) * * *$ & & $(-11.18)^{* * *}$ \\
\hline & & IMF Peg $*(1-$ JS Peg $)$ & $\begin{array}{c}-0.01236 \\
(-10.22)^{* * *}\end{array}$ \\
\hline Managed Floats & $\begin{array}{c}-0.01169 \\
(-10.89)^{* * *}\end{array}$ & $\begin{array}{l}\text { IMF Managed Float* } \\
(1-\text { JS Peg) }\end{array}$ & $\begin{array}{l}-0.00684 \\
(-6.68) * * *\end{array}$ \\
\hline \multirow{2}{*}{ DEV. vs. IND Dummy } & -0.00566 & & -0.00341 \\
\hline & $(-9.05) * * *$ & & $(-5.67) * * *$ \\
\hline \multirow{2}{*}{ IND vs. IND Dummy } & -0.01584 & & -0.01190 \\
\hline & $(-11.14)^{* * * *}$ & & $(-8.57)^{* * *}$ \\
\hline \multirow{2}{*}{ Constant } & -0.04077 & & -0.04217 \\
\hline & $(-9.51) * * *$ & & $(-8.94) * * *$ \\
\hline Obs. & 3415 & & 3415 \\
\hline RMSE & 0.0106 & & 0.0109 \\
\hline $\mathrm{R}^{\wedge} 2$ & 0.60 & & 0.58 \\
\hline
\end{tabular}

Notes: The dependent variable is bilateral exchange rate volatility between all currency pairs, as described in equation (2). White heteroscedasticity robust t-statistics are presented in the parentheses. RMSE is the root mean square residual. Asterisks, ***, **, *, denote the significance level at $1 \%, 5 \%$ and $10 \%$ respectively. Members of the same currency unions have been aggregated as single economies. High-inflation observations defined as $>40 \%$ in any year during the sample period have been excluded. The United States Dummy takes the value of one if the US dollar is one of the two currencies. 
Table A2 gives information about the countries which were classified by the IMF for at least part of the 1999-2006 period as basket pegs.

Appendix Table A2. IMF Basket Pegs in the Sample

\begin{tabular}{cccccc}
\hline $\begin{array}{c}\text { IFS } \\
\text { Code }\end{array}$ & Name & $\begin{array}{c}\text { JS_Anchoring } \\
\text { Currency }\end{array}$ & IMF_BP & $\begin{array}{c}\text { Regime in Previous } \\
\text { Classification }\end{array}$ & $\begin{array}{c}\text { Frequency in Previous } \\
\text { IMF_PEG Variable }\end{array}$ \\
\hline 181 & Malta & EURO & 0.83 & Conventional Peg & 1 \\
616 & Botswana & South Africa & 0.83 & Conventional Peg & 1 \\
618 & Burundi & United States & 0.067 & Conventional Peg & 0.067 \\
672 & Libya & United States & 1 & Conventional Peg & 1 \\
686 & Morocco & EURO & 1 & Conventional Peg & 1 \\
718 & Seychelles & United States & 0.6 & Conventional Peg & 1 \\
819 & Fiji & United States & 1 & Conventional Peg & 1 \\
846 & Vanuatu & United States & 1 & Conventional Peg & 1 \\
862 & Samoa & New Zealand & 1 & Conventional Peg & 1 \\
\hline
\end{tabular}

"IMF_BP" shows the proportion of the period for which the country is classified as a basket peg. 
Appendix Table A3. Data Sources

\begin{tabular}{|c|c|}
\hline Raw Data (in Bold fonts) & Database \\
\hline $\begin{array}{l}\text { Nominal Bilateral } \\
\text { Exchange Rates }\end{array}$ & $\begin{array}{l}\text { IMF International Financial Statistics (IFS) } \\
\text { Monthly End of Period NC/USD Rates }\end{array}$ \\
\hline $\begin{array}{l}\text { Bilateral Trade for } \\
\text { Openness } \\
\text { Multilateral Exchange Rates } \\
\text { Trade Weighted Distance }\end{array}$ & IMF Direction of Trade Statistics \\
\hline GDP for Openness & $\begin{array}{l}\text { World Bank World Development Indication (WDI) } \\
\text { Current value USD }\end{array}$ \\
\hline GDP for Cycle Asymmetry & (WDI) Constant 2000 USD \\
\hline Inflation for Inflation Variables & WDI \\
\hline $\begin{array}{l}\text { Inflation for } \\
\text { Real Exchange Rates }\end{array}$ & IFS monthly CPI \\
\hline GDP pc & WDI Constant 2000 USD \\
\hline $\begin{array}{l}\text { Land Area and Population for } \\
\text { Land Area p.c. }\end{array}$ & $W D I$ \\
\hline $\begin{array}{l}\text { Instrument Variables for } \\
\text { Logarithmic Distance } \\
\text { Common Language Dummy } \\
\text { Ever Colony Dummy } \\
\text { Landlockness }\end{array}$ & $\begin{array}{l}\text { Andrew Rose's Website: } \\
\text { http://faculty.haas.berkeley.edu/arose/RecRes.htm }\end{array}$ \\
\hline $\begin{array}{l}\text { JS Exchange Rate Regime } \\
\text { Classification }\end{array}$ & $\begin{array}{l}\text { Jay Shambaugh's Website: } \\
\text { http://www.dartmouth.edu/ jshambau }\end{array}$ \\
\hline $\begin{array}{l}\text { IMF De Facto Exchange Rate } \\
\text { Regime Classification }\end{array}$ & IMF Exchange Arrangements and Exchange Restrictions \\
\hline $\begin{array}{l}\text { Bilateral Distance for } \\
\text { Trade Weighted Distance }\end{array}$ & $\begin{array}{l}\text { CEPII's distances measure: } \\
\text { http://www.cepii.fr/ }\end{array}$ \\
\hline
\end{tabular}

